\title{
Review
}

\section{Human gastric cancer risk screening: From rat pepsinogen studies to the ABC method}

\author{
By Chie Furihata ${ }^{* 1, * 2, * 3, \dagger}$ \\ (Edited by Tadao KAKIzOE, M.J.A.)
}

\begin{abstract}
We examined the development of gastric cancer risk screening, from rat pepsinogen studies in an experimental rat gastric carcinogenesis model induced with $N$-methyl$N^{\prime}$-nitro- $N$-nitrosoguanidine (MNNG) and human pepsinogen studies in the 1970s and 1980s to the recent "ABC method" for human gastric cancer risk screening. First, decreased expression or absence of a major pepsinogen isozyme, PG1, was observed in the rat gastric mucosa from the early stages of gastric carcinogenesis to adenocarcinomas following treatment with MNNG. In the 1980s, decreases in PGI in the human gastric mucosa and serum were identified as markers of atrophic gastritis. In the 1990s, other researchers revealed that chronic infection with Helicobacter pylori $(\mathrm{Hp})$ causes atrophic gastritis and later gastric cancer. In the 2000s, a gastric cancer risk screening method combining assays to detect serum anti- $H p$ IgG antibody and serum PGI and PGII levels, the "ABC method", was established. Eradication of $H p$ and endoscopic follow-up examination after the ABC method are recommended to prevent gastric cancer.
\end{abstract}

Keywords: rat pepsinogen, human pepsinogen, DNA methylation, Helicobacter pylori, human gastric cancer risk screening, $\mathrm{ABC}$ method

\section{Introduction}

Gastric cancer remains one of the most common and fatal cancers worldwide, especially among older men. According to GLOBOCAN 2020 data, gastric

*1 Division of Molecular Target and Gene Therapy Products, National Institute of Health Sciences, Kawasaki, Kanagawa, Japan.

*2 Japan Research Foundation of Prediction, Diagnosis and Therapy for Gastric Cancer, Tokyo, Japan.

*3 School of Science and Engineering, Aoyama Gakuin University, Sagamihara, Kanagawa, Japan.

Correspondence should be addressed: C. Furihata, Division of Molecular Target and Gene Therapy Products, National Institute of Health Sciences, 3-25-26 Tonomachi, Kawasaki-ku, Kawasaki, Kanagawa 210-9501, Japan (e-mail: chiefurihata@ gmail.com).

Non-standard abbreviation list: ABC method: screening of gastritis $\mathrm{A}, \mathrm{B}, \mathrm{C}, \mathrm{D}$; BrdU: bromodeoxyuridine; CD: cathepsin Dlike acid proteinase; Cym: chymosin; DSSS: DNA single-strand scission; G type: gastric epithelial cell type; GI type: mixed gastric and intestinal cell type; Hp: Helicobacter pylori; I type: intestinal epithelial cell type; MNNG: $N$-methyl- $N$-nitro- $N$-nitrosoguanidine; MNU: $N$-methyl- $N$-nitrosourea; NCBI: National Center for Biotechnology Information; PAPG: PG1-altered pyloric gland; PG: pepsinogen; PGA: pepsinogen A (PGA3, PGA4, and PGA5); PGC: progastricsin; PGI: group I pepsinogens; PGII: group II pepsinogens; UDS: unscheduled DNA synthesis. cancer is the sixth most common neoplasm and the third most deadly cancer, with an estimated 768,793 deaths in 2020.1) In Japan, gastric cancer was the most deadly cancer until $1992,{ }^{2)}$ and was the second most common neoplasm and the third most deadly cancer in 2019. ${ }^{3)}$ The number of deaths due to gastric cancer in Japan was the highest at 50,680 in 1998, and gradually decreased to 43,000 in 2019. ${ }^{3)}$ However, the number of deaths caused by gastric cancer in older men remains high, at up to $350 / 100,000$ person-years at the age of $\left.85 .{ }^{5}\right)$

Animal models of chemical carcinogenesis have been used for many years in Japan. The first successful chemical carcinogenesis study in the world was conducted by Yamagiwa and Ichikawa in 1915, who generated carcinoma in the ear of a domestic rabbit using coal tar. ${ }^{6)}$ In the 1930s, Sasaki and Yoshida induced liver cancer in rats using orthoaminoazotoluene. ${ }^{7), 8)}$ Tumor production in the glandular stomach of rats induced by $N$-methyl- $N^{\prime}$-nitro$N$-nitrosoguanidine (MNNG), a known mutagen, was achieved by Sugimura and Fujimura in $\left.1967 .{ }^{9}\right)$ These findings initiated the study of gastric carcinogenesis in rat stomach using MNNG. 
Experimental rat gastric carcinogenesis studies using pepsinogen as a marker

Around 1970, it was postulated that gastric cancer was induced by chemical carcinogens in food or in the environment, or by chemical substances produced in the body. ${ }^{10)}$ Studies on the stomach were limited, and few suitable markers had been identified. In this era, pepsinogen was shown as a precursor of pepsin, a digestive enzyme, in the stomach. ${ }^{11)}$ Thus, a gastric carcinogenesis study using pepsinogen as a marker in the rat gland stomach mucosa was initiated under the supervision of Sugimura.

Decrease or absence of PG1 protein in the glandular stomach of rats during gastric carcinogenesis induced by MNNG. In the first notable study of gastric carcinogenesis, decreased or absent expression of a pepsinogen isozyme, PG1, was induced in the gastric mucosa after administration of MNNG to rats. ${ }^{12)-28)}$ Downregulated PG1 protein expression was induced in the pyloric mucosa as early as 1 week to 10 months after the administration of MNNG $(83 \mu \mathrm{g} / \mathrm{ml})$ to 8 -week-old male Wistar rats, as detected by polyacrylamide gel electrophoresis (Fig. 1). Decreased PG1 and PG2 expression, the latter a minor pepsinogen isozyme, was also observed in the fundic mucosa. Remarkable histopathological changes including atrophic changes were observed in the pyloric mucosa from 8 months after MNNG was administered, and rats showing such unusual histological alterations also had changes in their pepsinogen isozyme pattern. ${ }^{12)-14)}$

Other studies showed that downregulated PG1 protein expression induced by MNNG was observed in 28 of 30 well-differentiated adenocarcinomas and two adenomas in Wistar rat stomach ${ }^{15)}$ and in two of two transplantable well-differentiated adenocarcinomas induced by MNNG and 4-nitroquinoline 1oxide. ${ }^{15), 16)}$ Short-term (8 days) administration of MNNG induced DNA damage and heritable permanently reduced PG1 protein in the pyloric mucosa of inbred male Wistar rats. This effect was the response of newly arisen pyloric gland cells that were derived from stem cells modified by MNNG, and these modified stem cells continuously and irreversibly produced altered pyloric gland cells until at least 455 days. ${ }^{17)}$

Furthermore, dose-dependent induction of altered pyloric glands with low PG1 expression in Fischer rat stomach after the administration of MNNG for 5, 8, and 12 weeks was detected using an immunohistochemical assay with anti-PG1 serum.
Carcinogenesis in pylorus

Normal

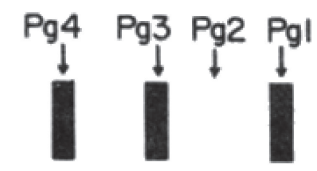

Precancerous change

Adenomo

Adenocarcinomo

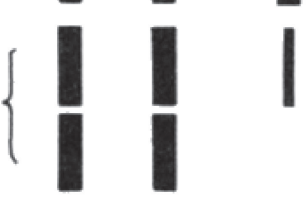

Corcinogenesis in fundus

Normal

Pyloric gland metoplasia

Adenocorcinoma

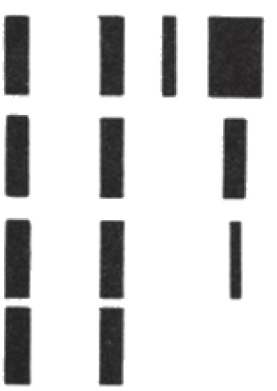

Normal development

Fetus

Newborn

(fundus, pylorus)

Adult fundus

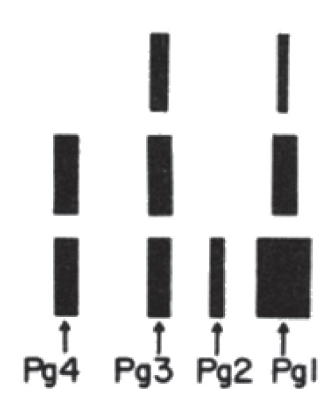

Fig. 1. Electropherogram of rat pepsinogens. Changes in pepsinogen isozyme patterns during stomach carcinogenesis and in normal development from fetus to adult. Pepsinogen extracts from samples were run on a $7.5 \%$ polyacrylamide gel in $50 \mathrm{mM}$ Tris-acetate buffer ( $\mathrm{pH} 8.2$ ). Then the gel was immersed in a solution of $0.65 \%$ hemoglobin in $60 \mathrm{mM} \mathrm{HCl}$, incubated in a humid chamber at $37^{\circ} \mathrm{C}$, and stained with $1 \%$ amido black $10 \mathrm{~B}$ in $7 \%$ acetic acid. Destaining was achieved in $7 \%$ acetic acid. ${ }^{13), 14), 41), 42)}$ Bands show relative quantity of pepsin derived from pepsinogen isozymes. Pg1, pepsinogen 1; Pg2, pepsinogen 2; Pg3, pepsinogen 3, Pg4, pepsinogen 4. "Normal" in "Carcinogenesis in pylorus or fundus" means normal pylorus and normal fundus.

The results suggest that the appearance of pyloric glands with low PG1 expression may be a preneoplastic change in gastric carcinogenesis. ${ }^{18)}$

In another experiment, male F344/Du Crj rats were given drinking water containing $100 \mathrm{pg} / \mathrm{ml}$ MNNG for 30 weeks and then normal tap water thereafter, and were examined in weeks 10, 20, 30, 40, 50 , and 70. After MNNG treatment, class III mucin- 
positive pyloric glands with low PG1 protein content in normal-looking pyloric mucosa were identified from week 10, and their number subsequently increased with time. Adenomatous hyperplasias were found from week 30 and adenocarcinomas were observed from week 50. These results suggested that the appearance of pyloric glands with low PG1 expression in normal-looking mucosa might be an immunohistochemically detectable preneoplastic change that precedes morphologically detectable preneoplastic changes in stomach carcinogenesis. ${ }^{19)}$

Another study analyzed the kinetics of PG1altered pyloric gland (PAPG) cells with low PG1 expression using double immunohistochemical staining for bromodeoxyuridine (BrdU) incorporation and PG1 in male WKY/N Crj rats treated with MNNG, as shown in Fig. 2. ${ }^{20)}$ After continuous BrdU administration, the life span of PAPG cells was estimated to be approximately $6-8$ days, whereas that of

\section{a}

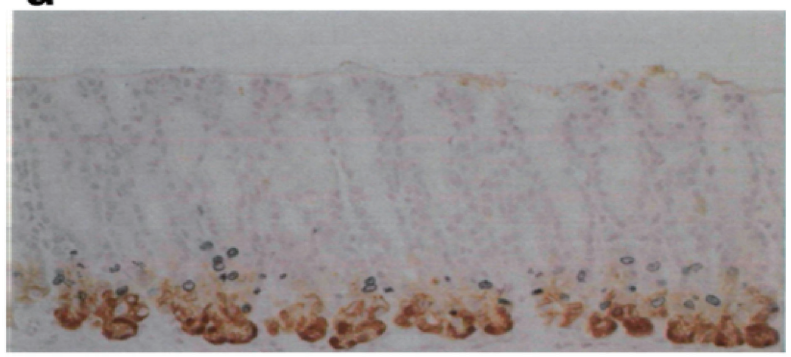

b

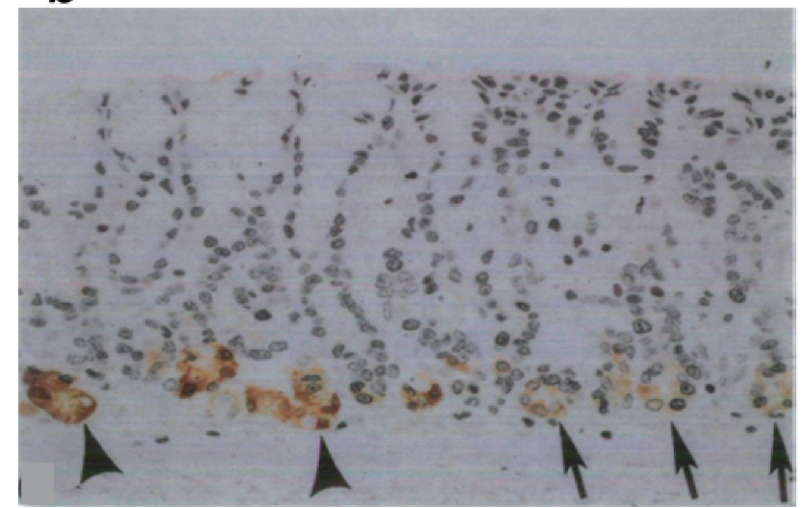

Fig. 2. Immunohistochemical staining of cells in PG1-altered pyloric gland (PAPG) with low PG1 protein content. Double immunohistochemical staining for BrdU and PG1 of normallooking pyloric mucosa treated with MNNG (100 $\mathrm{\mu g} / \mathrm{ml}$ MNNG in drinking water) undertaken 7 days after continuous labelling with BrdU. a, normal control. b, almost all cells in PAPG are labelled with BrdU (arrows). However, pyloric gland cells with high PG1 content located in the lower one-third of the pyloric gland (arrowheads) demonstrated no incorporation of BrdU. ${ }^{20)}$ normal pyloric gland cells was approximately 11-13 days. Thus, the data indicated that PAPG cells demonstrated a degree of independence from the pyloric glands with regards to the proliferation kinetics, which suggests that PAPG is a preneoplastic lesion involved in gastric carcinogenesis.

Finally, decreased pepsinogen content and PG1 in the pyloric mucosa of the rat stomach was induced in the pyloric mucosa of Wistar rat stomachs by short-term administration of MNNG and other stomach carcinogens, $N$-ethyl- $N^{\prime}$-nitro- $N$-nitrosoguanidine and $N$-propyl- $N^{\prime}$-nitro- $N$-nitrosoguanidine, but not by liver carcinogens, diethylnitrosamine, and dimethylnitrosamine. ${ }^{21), 22)}$

Aberrant methylation of PG1 during gastric carcinogenesis. It was demonstrated that DNA methylation affects PG1 gene expression in rat glandular stomach mucosa. ${ }^{29)-34)}$ Ichinose et al. revealed using methylation analysis with $\mathrm{MspI} / \mathrm{HpaII}$ and HhaI that there was an inverse correlation between DNA methylation and PG1 gene expression during normal stomach development. There was no detectable PG1 mRNA in either primary or transplanted Wistar-Imamichi rat gastric cancers induced by MNNG. Moreover, the methylation patterns of PG1 were different from those of normal tissues that expressed the gene and those that did not, and no simple correlation was observed between the methylation and expression of PG1. ${ }^{29)}$

In another study, administration of MNNG for 30 weeks to male WKY/NCrj rats induced PAPGs, adenomatous hyperplasias, and well-differentiated adenocarcinomas. Adenomatous hyperplasias and adenocarcinomas all consisted of gastric type cells resembling surface mucous cells or pyloric gland cells with little or no PG1 expression. In MNNG-induced gastric cancers generally lacking PG1, altered PG1 methylation was observed, with both CCGG and GCGC sites being methylated more than normal pyloric mucosa. These results suggest that the altered methylation of PG1 observed in gastric cancers is acquired early in the carcinogenic process, and that progressive changes in methylation occur with tumor development. ${ }^{30)}$

Intestinal metaplasia is important not as a precancerous lesion but rather as a paracancerous condition in rat gastric carcinogenesis. Tatematsu et al. hypothesized that intestinal metaplasia is important not as a precancerous lesion but rather as a paracancerous condition in various experimental animal gastric carcinogenesis models, including in rats treated with $\mathrm{MNNG}^{35)-38)}$ mice 
with $N$-methyl- $N$-nitrosourea (MNU), ${ }^{39)}$ and Mongolian gerbils with MNU and $H p{ }^{40)}$

Gastric adenocarcinomas induced by MNNG $(50 \mu \mathrm{g} / \mathrm{ml})$ in Wistar rats were examined using paradoxical concanavalin A staining and biochemical PG assay, which revealed that they were mainly composed of gastric-type tumor cells. Only gastric type cells were observed in 21 of 30 adenomatous hyperplasias and in 19 of 36 well-differentiated adenocarcinomas. The others consisted chiefly of gastric type cells but partly contained intestinal type cells. However, the percentage area of the intestinal type was extremely small, at less than $3.5 \%$. Adenomatous hyperplasias or well-differentiated adenocarcinomas composed only of intestinal type cells were not observed. These findings suggest that neoplastic germ cells produce mainly gastric type cells and sometimes intestinal type cells. Most tumor cells apparently originate from areas of mucosa composed of gastric type cells. ${ }^{35)}$

Rat pepsinogen isozymes. In a study examining the expression of pepsinogen, at least four pepsinogen isozymes (PG1, PG2, PG3, and PG4) from rat stomach mucosa were separated by electrophoresis on polyacrylamide gels, and PG1, PG2, PG3, and PG4 were present in the adult fundic mucosa; PG1 was the major PG isozyme in the adult fundic mucosa, as shown in Fig. 1.13),14),41)-43) Chief cells and mucous neck cells in the fundic mucosa were found to produce pepsinogen. ${ }^{41)-43)}$ PG1, PG3, and PG4 were present in the pyloric mucosa, and PG3 was relatively predominant at all stages after birth, whereby pepsinogen was produced by the pyloric gland cells. ${ }^{41)-46)}$

Differentiation of pepsinogen-producing cells was induced in the fundic mucosa but not in the pyloric mucosa of developing rats after birth to 30 days. In the fundic mucosa, increases in the peptic activity of pepsinogen, changes in the molecular species of pepsinogen isozymes separated by electrophoresis, and changes in the morphology of the chief cells indicated that maturation of the chief cells began around 15 days after birth and was complete 25-30 days after birth. In the pyloric mucosa, no changes in the peptic activity or molecular species of pepsinogen or morphology of pyloric gland cell occurred after birth. The isozymes pattern of adult pylorus was the same with newborn pylorus, as shown in Fig. 1.13),14),42) Injection of hydrocortisone or adrenocorticotropic hormone caused a precocious increase in peptide activity in the gastric mucosa in infant Wistar-Imamichi rats. ${ }^{41)}$ The differentiation of pepsinogen-producing cells was additionally studied. ${ }^{47)-50)}$

Four pepsinogen isozymes, PG1, PG2, PG3, and PG4 were purified and characterized from the fundic mucosa of male Wistar-Imamichi inbred adult rats. ${ }^{51)}$ The amino acid compositions of these four zymogens differed from each other but resembled those of pepsinogen Cs from various animal species. Activated and purified pepsin 1 from PG1 was a unique pepsin showing remarkable stability in alkaline conditions. It resembles pepsin A with respect to its inhibition by pepstatin and its amino acid composition, but had properties intermediate between those of pepsin $\mathrm{A}$ and pepsin $\mathrm{C}$ regarding its optimal $\mathrm{pH}$ (2.1 to 3.1$)$ with hemoglobin and its activity to N-acetyl-L-phenylalanyl-L-diiodotyrosine. Furthermore, rabbit antiserum prepared against PG1 reacted with PG2 but not with PG3 and PG4. ${ }^{51)}$

During stomach development, a progressive increase in PG1 mRNA that almost coincided with changes in the mucosal pepsinogen level and progressive demethylation after the onset of transcription was observed. Thus, there was an inverse correlation between the methylation and expression of PG1 genes, which suggests a role of DNA methylation in PG1 gene regulation during normal differentiation, although not in its primary role in gene activation. ${ }^{29)}$

Rat pepsinogen genes and proteins registered with the National Center for Biotechnology Information (NCBI). Three rat pepsinogen genes, Pgc, Pga5 and Cym, are registered with the NCBI. $P g c$ (official full name: progastricsin. gene ID: 24864, also known as PG1, location: chromosome 9) is registered as an adult rat pepsinogen gene. ${ }^{52)-54)}$ Additionally, Pga5 (official full name: pepsinogen A5, gene ID: 60372, neonatal zymogen of pepsins, location: chromosome 1) ${ }^{55), 56)}$ and Cym (official full name: chymosin, gene ID: 56825, location: chromosome 2, major neonatal pepsinogen $)^{57)}$ are registered as neonatal pepsinogen genes.

Three rat pepsinogen proteins (pepsinogen, pepsinogen $\mathrm{F}$ protein, and embryonic pepsinogen precursor) are registered in NCBI. Progastricsin (pepsinogen C) (392-amino acid protein, accession: AAA41827) is registered as an adult rat pepsinogen protein. ${ }^{58)}$ Additionally, pepsinogen $\mathrm{F}$ protein (pepsinogen 5, group I) (387-amino acid protein, accession: CAB75982 ${ }^{59)}$ and embryonic pepsinogen precursor (prochymosin) (379-amino acid protein, accession: NP_064476) ${ }^{60)}$ are registered as neonate/ infant-specific pepsinogens. 
Rat pepsinogen $\mathrm{C}$ has a similar amino acid composition to PG1 in Ref. 51. Rat pepsinogen F and prochymosin have a different amino acid composition to PG1-4 in Ref. 51.

\section{Additional studies on rat gastric carcinogenesis}

Induction of various biological responses by MNNG in rat gastric mucosa. MNNG induces unscheduled DNA synthesis (UDS, a marker of DNA damage), ${ }^{61), 62)}$ DNA single-strand scission (DSSS), ${ }^{62), 63)}$ c-fos and c-myc oncogene expression, ${ }^{64)}$ immune response gene expression [MHC class II, MHC class II-associated invariant chain, OX-62 (dendritic cell marker) and ED-1 (dendritic cell and macrophage common marker) $]^{65)-67)}$ and osteonectinexpressing cells ${ }^{68)}$ in the pyloric mucosa of rat stomach.

Screening of chemical gastric carcinogens and identification of $\mathrm{NaCl}$ as a gastric tumor promoter. In vivo short-term assays for tumor initiation and promotion in the glandular stomach of Fischer rats were undertaken. ${ }^{69), 70)}$ UDS and DSSS were used as markers of tumor-initiating activity, and replicative DNA synthesis and ornithine decarboxylase activity were analyzed as markers of tumorpromoting activity. ${ }^{69)-71)}$ The possible tumor-initiating and -promoting activities of glyoxyl, ${ }^{72), 73)}$ diacetyl, ${ }^{72)} 3$-diazo- $N$-nitrosobamethan, ${ }^{74)}$ hickory smoke condensate, ${ }^{75), 76)}$ omeprazole, ${ }^{77)-79)}$ nitrosated Oroxylum indicum Vent, ${ }^{80)}$ 2-chloro-4-methylthiobutanoic acid, ${ }^{81)}$ p-methylcatechol, ${ }^{82)}$ methylhydroquinone ${ }^{82)}$ and $N$-methyl- $N$-nitrosourea $(\mathrm{MNU})^{83)}$ were examined; however, strong chemical gastric carcinogens in foods or the environment or chemical substances in the body were not identified.

Conversely, $\mathrm{NaCl}$ was identified as a gastric tumor promoter by Takahashi and Tatematsu et al. ${ }^{84), 85)}$ We participated in studies on the possible tumor-promoting activities of $\mathrm{NaCl}^{86)-90)}$ and other chemicals. ${ }^{91)-98)}$

Epidemiologically, tobacco smoking is a known cause of gastric cancer. ${ }^{99)}$ Furthermore, a higher daily intake of alcohol was suggested to be associated with a higher risk of gastric cancer. ${ }^{100)}$

\section{Experimental mouse gastric carcinogenesis} studies using pepsinogen as a marker

PAPGs were also observed in an MNU-induced experimental model of gastric carcinogenesis induced various mouse strains including $\mathrm{BALB} / \mathrm{c}, \mathrm{C} 3 \mathrm{H}$, C57BL/6N, CBA, CD-1, DBA/2, and db/db diabetic mice. $^{101)-107)}$ Trp53 and ras gene mutations were rarely observed in mouse gastric tumors induced by MNU. ${ }^{108)}$

\section{Gastric carcinogenesis studies using pepsinogen as a marker in human gastric cancer}

Early human serum pepsinogen studies. Serum pepsinogen was identified at least 100 years ago. ${ }^{109)}$ The relationship between low serum pepsinogen and atrophic gastritis was suggested in at least the 1960s. ${ }^{110}$ ) Intensive human pepsinogen studies were initiated by Samloff et al. from around 1970, and the presence of pepsinogen isozymes in gastric mucosa, urine, and serum was detected by agar gel electrophoresis. ${ }^{111)-114)}$ There are two immunologically distinctive human pepsinogens, group I pepsinogens (PGI) and group II pepsinogens (PGII). ${ }^{111), 112)}$ Group I pepsinogens correspond with the main component of acid proteinases, pepsin, in gastric juice, and group II pepsinogens correspond with gastricsin. ${ }^{113)}$

The relationship between low pepsinogen proteins in human gastric mucosa and gastric cancer was reported in the $1970 \mathrm{~s}$ by Hirsch-Marie et al. ${ }^{115)}$ and Furihata et al., ${ }^{13)}$ and the relationship between low serum pepsinogen and gastric cancer was reported around 1980 by Samloff et al. ${ }^{116)}$ and Miki et al. ${ }^{117)}$

At least nine pepsinogen isozymes proteins (PG1-9) and a cathepsin D-like acid proteinase (CD) in the fundic mucosa were separated by polyacrylamide gel electrophoresis. In the pyloric mucosa, PG4, PG5, and CD were observed and PG2, PG3, and PG7-9 were occasionally observed, as shown in Fig. 3.13),118),119)

Decreased PGI in human gastric mucosa and serum during gastric carcinogenesis. To identify serum PGI and PGII, PGI and PGII were purified from gastric mucosa and prepared for radioimmunoassay. ${ }^{120)-122)}$ Enzyme-linked immunosorbent assays for serum PGI and PGII were further developed using monoclonal antibodies. ${ }^{123)-125)}$ This was the first human serum PGI and PGII assay kit using monoclonal antibodies globally. Chronic gastritis was studied using this kit, and useful biomarkers of atrophic gastritis (serum PGI and PGII and the PGI/PGII ratio) were established. ${ }^{126), 127)}$ Serum pepsinogen levels were measured in 137 patients with gastric cancer and compared with those of 288 normal cancer-free subjects. The serum pepsinogen levels of gastric cancer patients, especially PGI and the PGI/PGII ratio were significantly lower than those of normal controls and correlated well with the 


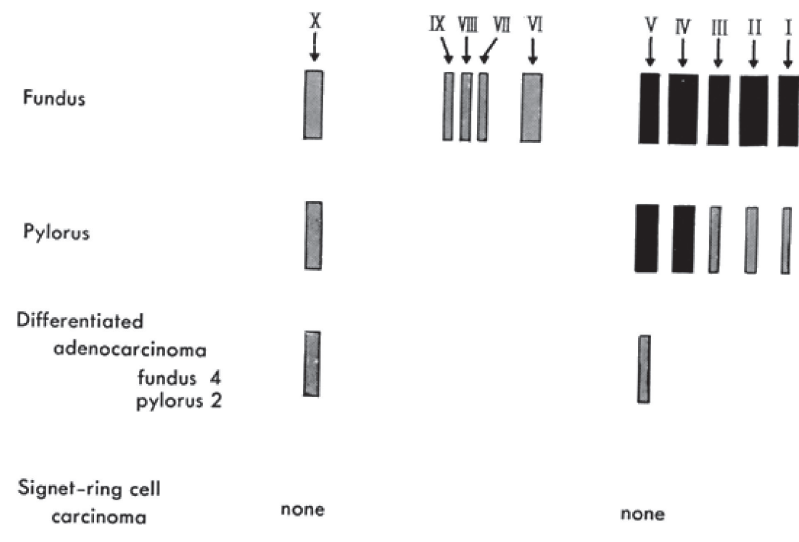

Fig. 3. Electropherogram of human pepsinogens. Pepsinogen extracts from samples were run on a $7.5 \%$ polyacrylamide gel After electrophoresis, the gel was treated as described in Fig. $1 .{ }^{13)}$ I, II, III, IV, V, VI, VII, VIII, IX and $\mathrm{X}$ are PG1, PG2, PG3, PG4, PG5, PG6, PG7, PG8, PG9 and CD. Band size and color density indicate the relative quantity of pepsin derived from pepsinogen isozyme. PG2 and PG4 are the major pepsinogens in the fundic mucosa and PG5 is the major pepsinogen in the pyloric mucosa.

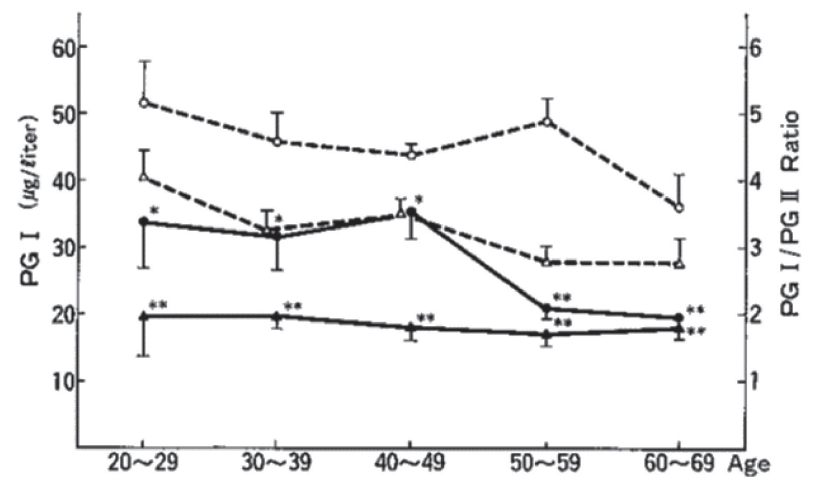

Fig. 4. Chronic changes in serum PGI and PGI/PGII ratio in cancer patients and cancer-free-subjects. The number of patients with cancer and cancer-free subjects in each age group were seven and 41 (20-29 years), 14 and 63 (30-39 years), 21 and 85 (40-49 years), 34 and 69 (50-59 years), and 61 and 30 (60-69 years), respectively. Control: $\bigcirc$, PgI; $\triangle$, PgI/PgII. Cancer: $\mathrm{PgI} ; \boldsymbol{\Delta}, \mathrm{PgI} / \mathrm{PgII}$. Vertical lines show the range of standard errors. Differences versus the cancer-free subjects: ${ }^{*}, \mathrm{P}<0.05$; **, $\mathrm{P}<0.001$ (Student's $t$-test). ${ }^{126}$ )

extent of chronic gastritis associated with the cancerous stomach, as shown in Fig. 4. ${ }^{126)}$ PGI levels gradually decreased, while those of PGII did not decrease, and a stepwise reduction in the PGI/II ratio was closely correlated with the progression from normal gastric mucosa to extensive atrophic gastritis. ${ }^{127)}$ This marker indicates a precancerous change in the stomach, rather being a tumor marker. ${ }^{128)}$ The high sensitivity and specificity of this non-invasive serum test to detect chronic gastritis suggested the possibility of its application to the mass screening of gastric cancer risk. Furthermore, the usefulness of gastric cancer risk screening using the serum pepsinogen test method was demonstrated in multiple studies. ${ }^{117), 129)-132)}$ In gastric cancer tissues and cancer cell lines, the expression of pepsinogen proteins was decreased or lost, correlating with their production. ${ }^{118)}$

Altered methylation of pepsinogen genes during human gastric carcinogenesis. Ichinose et al. reported that $\mathrm{PGA}$ and $\mathrm{PGC}$ genes are hypomethylated in tissues producing PGA and PGC, which suggests a role for DNA methylation in the regulation of their differential expression during normal differentiation. ${ }^{133), 134)}$ In gastric cancer tissues and cancer cell lines, no gross structural changes of the pepsinogen genes were observed, but the methylation patterns of the pepsinogen genes were found to be altered in different ways in various cancers. The functional significance of this altered methylation is unknown; however, these results suggest considerable heterogeneity in the methylation patterns of human gastric cancers. ${ }^{134), 135)}$ The observed correlation between altered DNA methylation levels and the activity of $H p$-related gastritis appears to be a relevant molecular mechanism underlying the development of diffuse-type cancer. ${ }^{136)}$ Furthermore, Ushijima et al. reported that comprehensive DNA methylation was observed in gastric cancer. ${ }^{137)-140)}$

Is intestinal metaplasia a preneoplastic change in human gastric cancer? Previously, Correa hypothesized that gastric carcinogenesis occurred in the following sequential stages: chronic gastritis; atrophy; intestinal metaplasia; and dysplasia. ${ }^{141)}$ He speculated that intestinal metaplasia is an essential step in gastric carcinogenesis but this is an ongoing research area. ${ }^{142), 143)}$

Tatematsu et al., however, proposed that intestinal metaplasia may not be a preneoplastic change in gastric carcinoma, but rather that intestinal type cells may appear independently in gastric cancer or in the gastric mucosa. ${ }^{118), 119)}$ Using a combined histochemical and immunohistochemical approach to detect mucin, they classified surgical specimens of 301 differentiated gastric cancers into three types: gastric epithelial cell (G) type, intestinal epithelial cell (I) type, and mixed gastric and intestinal cell (GI) type, according to the phenotypic differentiation of the component cancer cells. The 
proportion of $\mathrm{G}$ type cancers was $41.4 \%$ in early (tumor invasion of mucosa or submucosa) cases, decreasing to $22.2 \%$ in advanced (tumor invasion of muscularis propia or deeper) cases, whereas the proportion of I type cancers increased with progressive disease from $23.5 \%$ to $31.1 \%(\mathrm{P}<0.01)$. Cancer invading the subserosa or deeper included more I type cases and fewer $\mathrm{G}$ type cases than cancer limited to the mucosa $(\mathrm{P}<0.01)$. A phenotypic shift from $G$ to I type expression was observed with the progression of human differentiated gastric cancers. Intestinalization may occur independently in cancerous and non-cancerous gastric mucosa. ${ }^{144), 145)}$ Recently, a considerable number of studies raised the question as to whether intestinal metaplasia is a direct precursor of gastric cancer or merely a marker of high cancer risk in human gastric cancer. ${ }^{146), 147)}$

Human pepsinogen genes and proteins registered in NCBI. Pepsinogen A3, pepsinogen A4, and pepsinogen A5 (PGA3, PGA4 and PGA5) and progastricsin $(P G C)$ are registered in $\mathrm{NCBI} /$ Gene. $^{148)-152)}$ PGA3, PGA4 and PGA5 are located on chromosome 11, while $P G C$ (also known as $P G I I$ ) is located on chromosome 6 .

Regarding pepsinogen proteins, three pepsinogen A (group I) proteins (388-amino acids proteins pepsinogen 3 , pepsinogen 4 , and pepsinogen 5) are registered in NCBI/Protein. ${ }^{153)-155)}$ The amino acid compositions of these three proteins vary by just a few amino acids. In addition to pepsinogen $\mathrm{C}$ (progastricsin, 388 amino acids), gastricsin isoform 1 preproprotein (388 amino acids) and gastricsin isoform 2 preproprotein (315 amino acids) are registered in NCBI/Protein. ${ }^{156), 157)}$ The amino acid compositions of pepsinogen $\mathrm{C}$ and gastricsin isoform 1 preproprotein are identical, while that of gastricsin isoform 2 preproprotein differs after the 217th amino acid. Nonetheless, correlations between the electrophoretic patterns of human pepsinogen isozymes, genes, and proteins registered in NCBI have not been clarified.

\section{Carcinogenicity of chronic infection with $\mathrm{Hp}$}

The presence of spiral-shaped microorganisms in the human stomach was described more than 100 years ago by Jaworski. ${ }^{158)} \mathrm{Hp}$ was first identified in the human stomach in 1982 by Marshall and Warren. ${ }^{159)}$ There is sufficient evidence in humans for the carcinogenicity of chronic infection with $\mathrm{Hp}$ (Group 1). ${ }^{160), 161)}$ Chronic infection with $H p$ causes non-cardiac gastric cancer and low-grade B-cell
MALT gastric lymphoma, ${ }^{160)}$ while chronic infection with $H p$ CagA-positive strains is the strongest risk factor of gastric cancer. CagA protein is delivered into gastric epithelial cells via bacterial type IV secretion. ${ }^{162)} H p$ infection is now recognized as the main acquired factor involved in the pathogenesis of peptic ulcer disease and chronic gastritis ${ }^{163)}$ as well as gastric cancer. Furthermore, a relationship between $H p$ and serum pepsinogens in asymptomatic Japanese population was reported. ${ }^{163), 164)}$

$H p$ infection occurs during childhood, most commonly before 5 years of age. In Japan, older generations born before around 1950 show a high prevalence of $H p$ infection of approximately $80-90 \%$, decreasing with age to approximately $10 \%$ or less in those born in the 1990s, and less than $2 \%$ of children born after 2000. ${ }^{165)}$ Once infection is established, it usually lasts for life unless treated. ${ }^{161)}$ $H p$ infection is generally treated with a 1-week regimen of triple therapy consisting of an antisecretory agent and two antibiotics. ${ }^{166)}$ Eradication of $\mathrm{Hp}$ decreases the severity of gastritis, producing significant changes in serum PG levels, including the serum PGI to PGII ratio. ${ }^{167)}$

\section{ABC method}

Asaka and Miki initiated a study of the relationship between anti- $H p$ IgG antibody and serum pepsinogen in the 1990 s. $^{163), 164), 168)}$ Miki et al. proposed a new gastric cancer risk screening method by combining the assays for serum anti- $H p$ IgG antibody and serum pepsinogen level (PGI and PGI/PGII ratio) detection and categorizing the findings into four groups, where PG-negative means normal control PG, and PG-positive indicates that PGI and the PGI/PGII ratio are significantly lower than those of normal controls: A ( $H p$-negative, PGnegative); B ( $H p$-positive, PG-negative); C ( $H p$ positive, PG-positive); and $\mathrm{D}$ (Hp-negative, PGpositive). ${ }^{169)-172)}$

Miki established the ABC method in 2011. ${ }^{171}$ ) Subjects were classified into one of four risk groups on the basis of the results of the two serologic tests for anti- $H p$ IgG antibody titers and PGI and PGII levels: Group A $[H p(-)$, PG (-)], infection-free subjects; Group B $[H p(+), \mathrm{PG}(-)]$, chronic atrophic gastritis (CAG)-free or mild; Group C $[H p(+) \mathrm{PG}(+)]$, CAG; and Group D $[H p(-) \mathrm{PG}(+)]$, severe CAG with extensive intestinal metaplasia. Continuous endoscopic follow-up examinations are required to detect the early stages of gastric cancer. Asymptomatic Group A, which accounts for $50-80 \%$ of subjects, 
may be excluded from the secondary endoscopic examination for efficiency. $H p$-infected subjects should be administered eradication treatment aimed at the prevention of gastric cancer.

\section{Application of the ABC method in gastric cancer risk screening}

Hundreds of studies were reported in various countries on serum anti- $H p$ IgG antibody, serum PG levels, and human gastric cancer ${ }^{167)-185)}$ after Miki published the ABC method in 2011. ${ }^{171)}$

Ichinose et al. reported a 16-year prospective study of 4,655 healthy asymptomatic subjects (men aged 40-59 years at the start of the study) in Wakayama in Japan, which demonstrated that the combination of $H p$ antibody and serum PG was a good predictive tool of gastric cancer incidence. In subjects with a serologically diagnosed healthy stomach (Hp-negative, PG-negative), the cancer incidence rate was low, at 16/100,000 person-years. With the establishment of $H p$ infection and the progression of chronic gastritis, significant stepwise cancer risk elevations were observed in chronic atrophic gastritis (CAG)-free subjects ( $H p$-positive, PG-negative) [hazard ratio (HR) 8.9, 95\% confidence interval (CI) 2.7-54.7] to subjects with CAG ( $\mathrm{Hp}$ positive, PG-positive) (HR 17.7, 95\% CI 5.4-108.6), and finally to subjects with metaplastic gastritis (Hp-negative, PG-positive) (HR 69.7, 95\% CI 13.6502.9). ${ }^{174)}$ These results clearly indicated that serum levels of PG and $H p$ antibody titers provided indices of cancer development in $H p$-infected subjects.

Song et al. showed that the combination of PGI and $H p$ antibody was useful for predicting gastric cancer in their large Finnish cohort. ${ }^{180)}$ Serum PGI (sPGI) measurements were available for 21,895 Finnish male smokers. In a subset $(\mathrm{n}=3,555)$ with anti- $H p$ serology, groups B, C, and D had increased gastric cancer ORs of 1.79 (95\% CI 1.21-2.64), 3.85 (95\% CI 2.36-6.28), and 6.35 (95\% CI 2.2018.34), respectively. Low sPGI was associated with increased gastric cancer risk in their cohort. Thus, a single measurement of sPGI along with $H p$ wholecell measurements and CagA serology provides a potentially useful prediction tool for gastric cancer risk.

The ABC method has been confirmed as a valid approach for gastric cancer risk screening. Leja et al. conducted the GISTAR study, which was a multicentric randomized study of $H p$ eradication and pepsinogen testing for the prevention of gastric cancer mortality. ${ }^{181)}$ Furthermore, a statistical study confirmed that the ABC method is useful for the estimation of gastric cancer lifetime cumulative incidence risk and risk of mortality. ${ }^{182)}$ The "Gastric Cancer Checklist" (https://epi.ncc.go.jp/riskcheck/ gastric/, in Japanese) of the division of Public Health/Health Science/Hygiene, National Cancer Center Research Institute, Japan, also incorporates the ABC method.

A combination of assays for the presence of serum anti- $H p$ IgG antibody and serum PG concentration can be used to screen for gastric cancer risk. In Japan, serum anti- $H p$ IgG antibody and serum PG assays plus scheduled endoscopy is a costeffective method for the screening of gastric cancer risk. ${ }^{183)}$

$H p$ eradication can change $\mathrm{PG}$ levels and serum $H p$ sero-positivity and $H p$ eradicated individuals should be excluded from the ABC method. Further investigation for these individuals is necessary regarding screening of gastric cancer risk.

\section{Conclusion}

Pepsinogen studies in an experimental rat gastric carcinogenesis model induced by a chemical carcinogen, MNNG, is a good model for the study of human gastric cancer. However, it was recognized in the 1990s that $H p$ infection is the main acquired factor involved in the pathogenesis of peptic ulcer disease and chronic gastritis, alongside gastric cancer. Decreased or absent PG1 protein in the rat gastric mucosa, from the early stage of MNNG-induced gastric carcinogenesis to adenocarcinomas, was identified in the 1970s, and aberrant DNA methylation of PG1 in an experimental gastric carcinogenesis model induced by MNNG was reported in the 1980s. It was proposed that intestinal metaplasia is important not as a precancerous lesion but rather as a paracancerous condition. In the 1980s, it was demonstrated that decreased expression of the major pepsinogen isozyme, PGI, in the human gastric mucosa and serum is a marker of atrophic gastritis, a precancerous lesion of gastric cancer, and the DNA methylation patterns of the pepsinogen genes were found to be altered in different ways in human gastric cancer. It was proposed that intestinal metaplasia may not be a preneoplastic change in gastric carcinoma, but rather that intestinal type cells may appear independently in gastric cancer or in the gastric mucosa. A trial of gastric cancer risk screening using serum PGI and the PGI/PGII ratio was undertaken in the 1980s. In 2011, Miki established the ABC method using a combined assay for serum 
$H p$ IgG antibody and serum PG levels. The ABC method plus scheduled endoscopy is a cost-effective method of gastric cancer risk screening in Japan, and $H p$-infected subjects should be administered eradication treatment aimed at the prevention of gastric cancer and the current $\mathrm{ABC}$ method may be improved with the progress of future research.

\section{Acknowledgements}

I express my sincere thanks to my initial supervisor, Prof. Takashi Sugimura (Department of Molecular Oncology, Institute of Medical Science, The University of Tokyo; National Cancer Center Research Institute) of the rat pepsinogen studies in rat gastric carcinogenesis induced with MNNG. I also thank the many collaborators in my rat pepsinogen studies; especially, Drs. Masae Tatematsu (First Department of Pathology, Nagoya City University Medical School; Laboratory of Pathology, Aichi Cancer Center Research Institute), Michihito Takahashi (First Department of Pathology, Nagoya City University Medical School; Division of Pathology, National Institute of Hygienic Sciences), Takashi Kawachi (Division of Biochemistry, National Cancer Center Research Institute), Taijiro Matsushima (Department of Molecular Oncology, Institute of Medical Science, The University of Tokyo), and Tsutomu Katsuyama (Department of Pathology, Shinshu University). I thank my collaborators in my human pepsinogen studies in human gastric carcinogenesis; especially, Drs. Kazumasa Miki (First Department of Internal Medicine, Faculty of Medicine, The University of Tokyo; First Department of Internal Medicine, Faculty of Medicine, Toho University; Japan Research Foundation of Prediction, Diagnosis and Therapy for Gastric Cancer), Masao Ichinose (First Department of Internal Medicine, Faculty of Medicine, The University of Tokyo; Second Department of Internal Medicine, School of Medicine, Wakayama Medical University), Kenji Takahashi (Department of Biochemistry, Primate Research Institute, Kyoto University; Department of Biophysics and Biochemistry, Faculty of Science, The University of Tokyo), Takashi Kageyama (Department of Biochemistry, Primate Research Institute, Kyoto University), and Shunmei Furihata (Hygiene Department, Adachi-ku, Tokyo Metropolitan Government; Japan Research Foundation of Prediction, Diagnosis and Therapy for Gastric Cancer). Finally, I thank H. Nikki March, PhD, from Edanz Group (https://jp.edanz.com/ac) for editing a draft of this manuscript.

\section{References}

1) Sung, H., Ferlay, J., Siegel, R.L., Laversanne, M., Soerjomataram, I., Jemal, A. et al. (2021) Global cancer statistics 2020: GLOBOCAN estimates of incidence and mortality worldwide for 36 cancers in 185 countries. CA Cancer J. Clin. 71, 209-249.

2) The Editorial Board of the Cancer Statistics in Japan (2021) 20. Trends in age-adjusted mortality rate (1958-2019). In Cancer Statistics in Japan 2021. Foundation for Promotion of Cancer Research (FPCR), Tokyo, pp. 42-43.

3) The Editorial Board of the Cancer Statistics in Japan (2021) 1. Projection of cancer mortality and incidence in 2020. In Cancer Statistics in Japan 2021. Foundation for Promotion of Cancer Research (FPCR), Tokyo, p. 15.

4) Cancer Statistics. Cancer Information Service, National Cancer Center, Japan (Vital Statistics of Japan, Ministry of Health, Labour and Welfare). https://ganjoho.jp/reg_stat/statistics/dl/index. html \#mortality.

5) The Editorial Board of the Cancer Statistics in Japan (2021) 21. Trends in age-specific mortality rate $(1965,1990,2019)$. In Cancer Statistics in Japan 2021. Foundation for Promotion of Cancer Research (FPCR), Tokyo, p. 44.

6) Yamagiwa, K. and Ichikawa, K. (1918) Experimental study of the pathogenesis of carcinoma. Cancer Res. 3, 1-29.

7) Yoshida, T. (1933) Über die serienweise Verfolgung der Veränderungen der Leber der experimentellen Hepatomerzeugung durch $o$-aminoazotuol. Trans. Jpn. Pathol. Soc. 23, 636-638.

8) Sasaki, T. and Yoshida, T. (1935) Experimentelle Erzeugung des Lebercarcinoms durch Fütterung mit o-Amidoazotoluol. Virchows Arch. path. Anat. 295, 175-200.

9) Sugimura, T. and Fujimura, S. (1967) Tumour production in glandular stomach of rat by $N$ methyl- $N$-nitro- $N$-nitrosoguanidine. Nature 216, 943-944.

10) Correa, P., Haenszel, W., Cuello, C., Tannenbaum, S. and Archer, M. (1975) A model for gastric cancer epidemiology. Lancet 2, 58-60.

11) Seastone, C.V. and Herriott, R.M. (1937) Immunological studies on pepsin and pepsinogen. J. Gen. Physiol. 20, 797-806.

12) Furihata, C., Sasajima, K., Kazama, S., Kogure, K. and Kawachi, T. (1975) Changes in pepsinogen isozymes in stomach carcinogenesis induced in rats by $N$-methyl- $N^{\prime}$-nitro- $N$-nitrosoguanidine. J. Natl. Cancer Inst. 55, 925-930.

13) Furihata, C., Tatematsu, M., Shirai, T., Yokochi, K., Takahashi, M. and Sugimura, T. (1977) Pepsinogens and stomach cancer. In Pathology of Carcinogenesis in Digestive Organs (eds. Farber, E., Kawachi, T. and Nagayo, T.). University of Tokyo Press, Tokyo/University Park Press, Baltimore, pp. 49-63.

14) Furihta, C., Kawachi, T., Sasajima, S., Matsukura, N., Sugimura, T. and Matsuda, A. (1978) 
Experimental stomach carcinogenesis. In Gastrointestinal Tumors - A Clinical and Experimental Approach (ed. Gerard, A.). Pergamon Press, Oxford, pp. 31-37.

15) Tatematsu, M., Furihata, C., Hirose, M., Shirai, T. and Ito, N. (1977) Changes in pepsinogen isozymes in stomach cancers induced in Wistar rats by $N$-methyl- $N^{\prime}$-nitro- $N$-nitrosoguanidine and in transplantable gastric carcinoma (SG2B). J. Natl. Cancer Inst. 58, 1709-1716.

16) Kokubo, T., Takahashi, M., Kurokawa, Y., Miyahara, M., Furihata, C. and Matsushima, T. (1981) Preservation of gastric gland character in transplantable gastric adenocarcinoma (SG2B) of rats. Gan $\mathbf{7 2}, 583-589$.

17) Tatematsu, M., Saito, D., Furihata, C., Miyata, Y., Nakatsuka, T., Ito, N. et al. (1980) Initial DNA damage and heritable permanent change in pepsinogen isoenzyme pattern in the pyloric mucosae of rats after short-term administration of $N$-methyl- $N^{\prime}$-nitro- $N$-nitrosoguanidine. J. Natl. Cancer Inst. 64, 775-781.

18) Tatematsu, M., Furihata, C., Mera, Y., Shirai, T., Matsushima, T. and Ito, N. (1986) Immunohistochemical demonstration of induction of pyloric glands with low pepsinogen $1(\mathrm{Pg} 1)$ content in rat stomach by $N$-methyl- $N^{\prime}$-nitro- $N$-nitrosoguanidine. Jpn. J. Cancer Res. 77, 238-243.

19) Tatematsu, M., Furihata, C., Katsuyama, T., Mera, Y., Inoue, T., Matsushima, T. et al. (1987) Immunohistochemical demonstration of pyloric gland-type cells with low-pepsinogen isozyme 1 in preneoplastic and neoplastic tissues of rat stomachs treated with $N$-methyl- $N^{\prime}$-nitro- $N$-nitrosoguanidine. J. Natl. Cancer Inst. 78, 771-777.

20) Tatematsu, M., Mutai, M., Aoki, T., de Camargo, J.L., Furihata, C. and Ito, N. (1989) Proliferation kinetics of pepsinogen altered pyloric gland cells in rats treated with $N$-methyl- $N^{\prime}$-nitro- $N$-nitrosoguanidine. Carcinogenesis 10, 907-911.

21) Furihata, C., Kodama, K. and Matsushima, T. (1981) Induction of changes in the pepsinogen content and the pepsinogen isoenzyme pattern of the pyloric mucosa of the rat stomach by shortterm administration of stomach carcinogens. J. Natl. Cancer Inst. 67, 1101-1104.

22) Tatematsu, M., Ozaki, K., Mutai, M., Shichino, Y., Furihata, C. and Ito, N. (1990) Enhancing effects of various gastric carcinogens on development of pepsinogen-altered pyloric glands in rats. Carcinogenesis 11, 1975-1978.

23) Tatematsu, M., Aoki, T., Asamoto, M., Furihata, C. and Ito, N. (1987) Enhancing effects of $N$-ethyl$N^{\prime}$-nitro- $N$-nitrosoguanidine and sodium taurocholate on development of pepsinogen 1 decreased pyloric glands in rats initiated with $N$-methyl- $N^{\prime}$ nitro- $N$-nitrosoguanidine. Jpn. J. Cancer Res. 78, $312-316$.

24) Tatematsu, M., Aoki, T., Inoue, T., Mutai, M., Furihata, C. and Ito, N. (1988) Coefficient induction of pepsinogen 1-decreased pyloric glands and gastric cancers in five different strains of rats treated with $N$-methyl- $N^{\prime}$-nitro- $N$-nitrosoguanidine. Carcinogenesis 9, 495-498.

25) Tatematsu, M., Mutai, M., Inoue, K., Ozaki, K., Furihata, C. and Ito, N. (1989) Synergism between sodium chloride and sodium taurocholate and development of pepsinogen-altered pyloric glands: relevance to a medium-term bioassay system for gastric carcinogens and promoters in rats. Jpn. J. Cancer Res. 80, 1035-1040.

26) Yamaguchi, S., Tatematsu, M., Furihata, C., Takaba, K. and Ito, N. (1990) Effects of bile acids on development of pepsinogen-altered pyloric glands in rats. Cancer Lett. 55, 129-134.

27) Tatematsu, M., Katsuyama, T., Furihata, C., Fukushima, S., Shirai, T., Kato, T. et al. (1990) Cellular differentiation and histogenesis of rat glandular stomach cancers. Jpn. J. Cancer Res. 81, 760-767.

28) Ogawa, K., Shichino, Y., Tatematsu, M., Furihata, C., Asamoto, M., Nagase, S. et al. (1995) Increasing development of pepsinogen-altered pyloric glands and adenocarcinoma in glandular stomach of analbuminemic rats. Cancer Lett. 96, 219-224.

29) Ichinose, M., Miki, K., Furihata, C., Tatematsu, M., Ichihara, Y., Ishihara, T. et al. (1988) DNA methylation and expression of the rat pepsinogen gene in embryonic, adult, and neoplastic tissues. Cancer Res. 48, 1603-1609.

30) Tatematsu, M., Ichinose, M., Tsukada, S., Kakei, N., Takahashi, S., Ogawa, K. et al. (1993) DNA methylation of the pepsinogen 1 gene during rat glandular stomach carcinogenesis induced by $N$ methyl- $N$-nitro- $N$-nitrosoguanidine or catechol. Carcinogenesis 14, 1415-1419.

31) Niwa, T., Yamashita, S., Tsukamoto, T., Kuramoto, T., Nomoto, T., Wakazono, K. et al. (2005) Whole-genome analyses of loss of heterozygosity and methylation analysis of four tumorsuppressor genes in $N$-methyl- $N^{\prime}$-nitro- $N$-nitrosoguanidine-induced rat stomach carcinomas. Cancer Sci. 96, 409-413.

32) Ichinose, M., Miki, K., Tatematsu, M., Furihata, C., Matsushima, M., Ichihara, Y. et al. (1990) Hydrocortisone-induced enhancement of expression and changes in methylation of pepsinogen genes in stomach mucosa of the developing rat. Biochem. Biophys. Res. Commun. 172, 1086-1093.

33) Ichinose, M., Miki, K., Tatematsu, M., Mizuno, T., Mutai, M., Furihata, C. et al. (1988) Cell-specific hypomethylation of the pepsinogen gene in pepsinogen-producing cells. Biochem. Biophys. Res. Commun. 155, 670-677.

34) Fukuda, K., Ichinose, M., Saiga, H., Shiokawa, K. and Yasugi, S. (1994) Developmental changes of DNA methylation pattern of embryonic chick pepsinogen gene. J. Biochem. 115, 502-506.

35) Tatematsu, M., Furihata, C., Katsuyama, T., Hasegawa, R., Nakanowatari, J., Saito, D. et al. (1983) Independent induction of intestinal metaplasia and gastric cancer in rats treated with $N$ methyl- $N^{\prime}$-nitro- $N$-nitrosoguanidine. Cancer Res. 
43, 1335-1341.

36) Tatematsu, M., Katsuyama, T., Furihata, C. Tsuda, H. and Ito, N. (1984) Stable intestinal phenotypic expression of gastric and small intestinal tumor cells induced by $N$-methyl- $N$ '-nitro$N$-nitrosoguanidine or methylnitrosourea in rats. Gan 75, 957-965.

37) Yuasa, H., Hirano, K., Kodama, H., Nakanishi, H., Imai, T., Tsuda, H. et al. (1994) Immunohistochemical demonstration of intestinal-type alkaline phosphatase in stomach tumors induced by $N$ methyl- $N^{\prime}$-nitro- $N$-nitrosoguanidine in rats. Jpn. J. Cancer Res. 85, 897-903.

38) Kobayasi, S., Rodrigues, M., de Camargo, J.L., Imai, T., Yuasa, H., Ogawa, K. et al. (1994) Gastric and small intestinal lesions after partial stomach resection with Billroth II or Roux-en-Y reconstruction in the rat. Cancer Lett. 85, 73-82.

39) Tatematsu, M., Tsukamoto, T. and Inada, K. (2003) Stem cells and gastric cancer: role of gastric and intestinal mixed intestinal metaplasia. Cancer Sci. 94, 135-141.

40) Maruta, F., Ota, H., Genta, R.M., Sugiyama, A., Tatematsu, M., Katsuyama, T. et al. (2001) Role of $N$-methyl- $N$-nitrosourea in the induction of intestinal metaplasia and gastric adenocarcinoma in Mongolian gerbils infected with Helicobacter pylori. Scand. J. Gastroenterol. 36, 283-290.

41) Furihata, C., Kawachi, T. and Sugimura, T. (1972) Premature induction of pepsinogen in developing rat gastric mucosa by hormones. Biochem. Biophys. Res. Commun. 47, 705-711.

42) Furihata, C., Iwasaki, Y., Sugimura, T., Tatematsu, M. and Takahashi, M. (1973) Differentiation of pepsinogen-producing cells in the fundic and pyloric mucosa of developing rats. Cell Differ. 2, 179-189.

43) Tatematsu, M., Takahashi, M., Tsuda, H., Hirose, M. and Furihata, C. (1975) Precocious differentiation of immature chief cells in fundic mucosa of infant rats induced by hydrocortisone. Cell Differ. 4, 285-294.

44) Tatematsu, M., Katsuyama, T., Furihata, C., Fukushima, S., Shirai, T., Kato, T. et al. (1990) Cellular differentiation and histogenesis of rat glandular stomach cancers. Jpn. J. Cancer Res. 81, 760-767.

45) Suzuki, S., Furihata, C., Tsuyama, S. and Murata, F. (1983) Immunocytochemical localization of pepsinogen in rat stomach. Histochemistry $\mathbf{7 9}$, $167-176$.

46) Murata, F., Suzuki, S., Tsuyama, S., Suganuma, T., Imada, M. and Furihata, C. (1985) Application of rapid freezing followed by freeze-substitution acrolein fixation for cytochemical studies of the rat stomach. Histochem. J. 17, 967-980.

47) Shirai, T., Furihata, C., Tatematsu, M., Fukushima, S. and Ito, N. (1976) Biochemical study of pyloric metaplasia in the mucosa regenerating over iodoacetamide-induced fundic ulcers in rat stomach. Gan 67, 813-817.

48) Mizuno, T., Furihata, C., Takeda, H., Suematsu, N. and Lasnitzki, I. (1990) Heterotypic induction of stomach-like glands in the urogenital sinus endoderm under the influence of stomach mesenchyme of foetal rats. Rouxs Arch. Dev. Biol. 198, 483487.

49) Fukamachi, H., Ichinose, M., Ishihama, S., Tsukada, S., Yasugi, S., Shiokawa, K. et al. (1994) Fetal rat glandular stomach epithelial cells differentiate into surface mucous cells which express cathepsin $\mathrm{E}$ in the absence of mesenchymal cells in primary culture. Differentiation 56, 83-89.

50) Tsukada, S., Ichinose, M., Yahagi, N., Matsubara, Y., Yonezawa, S., Shiokawa, K. et al. (1998) Induction of precocious pepsinogen synthesis by glucocorticoids in fetal rat gastric epithelium in organ culture: importance of mesenchyme for epithelial differentiation. Differentiation 62, 239247.

51) Furihata, C., Saito, D., Fujiki, H., Kanai, Y., Matsushima, T. and Sugimura, T. (1980) Purification and characterization of pepsinogens and a unique pepsin from rat stomach. Eur. J. Biochem. 105, 43-50.

52) Pgc (progastricsin) [Rattus norvegicus (Norway rat)]. Gene ID: 24864. NCBI, Bethesda, MD, U.S.A. https://www.ncbi.nlm.nih.gov/gene/24864.

53) Ichihara, Y., Sogawa, K., Morohashi, K., FujiiKuriyama, Y. and Takahashi, K. (1986) Nucleotide sequence of a nearly full-length cDNA coding for pepsinogen of rat gastric mucosa. Eur. J. Biochem. 161, 7-12.

54) Ishihara, T., Ichihara, Y., Hayano, T., Katsura, I., Sogawa, K., Fujii-Kuriyama, Y. et al. (1989) Primary structure and transcriptional regulation of rat pepsinogen $\mathrm{C}$ gene. J. Biol. Chem. 264, 10193-10199.

55) Pga5 (pepsinogen A5) [Rattus norvegicus (Norway rat)]. Gene ID: 60372. NCBI, Bethesda, MD, U.S.A. https://www.ncbi.nlm.nih.gov/gene/60372.

56) Kageyama, T., Ichinose, M., Tsukada-Kato, S., Omata, M., Narita, Y., Moriyama, A. et al. (2000) Molecular cloning of neonate/infant-specific pepsinogens from rat stomach mucosa and their expressional change during development. Biochem. Biophys. Res. Commun. 267, 806-812.

57) Cym (chymosin) [Rattus norvegicus (Norway rat)]. Gene ID: 56825. NCBI, Bethesda, MD, U.S.A. https://www.ncbi.nlm.nih.gov/gene/56825.

58) pepsinogen [Rattus norvegicus]. GenBank: AAA41827.1. NCBI, Bethesda, MD, U.S.A. https://www.ncbi.nlm.nih.gov/protein/AAA41827.

59) pepsinogen F protein [Rattus norvegicus]. GenBank: CAB75982.1. NCBI, Bethesda, MD, U.S.A. https://www.ncbi.nlm.nih.gov/protein/CAB75982.

60) embryonic pepsinogen precursor [Rattus norvegicus]. NCBI Reference Sequence: NP_064476.2. NCBI, Bethesda, MD, U.S.A. https://www.ncbi. nlm.nih.gov/protein/NP_064476.

61) Furihata, C., Yamawaki, Y., Jin, S.S., Moriya, H., Kodama, K., Matsushima, T. et al. (1984) Induction of unscheduled DNA synthesis in rat stomach mucosa by glandular stomach carcino- 
gens. J. Natl. Cancer Inst. 72, 1327-1334.

62) Ohsawa, K., Furihata, C., Mori, M. and Ikui, E. (1993) Ability of $N$-methyl- $N$-nitro- $N$-nitrosoguanidine, 4-nitroquinoline 1-oxide, dimethylnitrosamine, and $\mathrm{NaCl}$ to induce unscheduled DNA synthesis, stimulate replicative DNA synthesis, and produce DNA single-strand breaks in pyloric mucosa of rat stomach. Mutat. Res. 287, 307-319.

63) Furihata, C., Ikui, E. and Matsushima, T. (1996) DNA single-strand scission in the pyloric mucosa of rat stomach induced by four glandular stomach carcinogens and three other chemicals. Mutat. Res. 368, 1-6.

64) Furihata, C., Yamakoshi, A., Hatta, A., Tatematsu, M., Iwata, H., Hayashi, K. et al. (1994) Induction of $c$-fos and $c$-myc oncogene expression in the pyloric mucosa of rat stomach by $N$-methyl- $N^{\prime}$ nitro- $N$-nitrosoguanidine and taurocholate. Cancer Lett. 83, 215-220.

65) Furihata, C., Oka, M., Yamamoto, M., Ito, T., Ichinose, M., Miki, K. et al. (1997) Differentially expressed MHC class II-associated invariant chain in rat stomach pyloric mucosa with $N$-methyl- $N^{\prime}$ nitro- $N$-nitrosoguanidine exposure. Cancer Res. 57, 1416-1418.

66) Oka, M., Furihata, C., Kitoh, K., Yamamoto, M., Tatematsu, M., Ichinose, M. et al. (1998) Involvement of dendritic cell response to resistance of stomach carcinogenesis caused by $N$-methyl- $N^{\prime}-$ nitro- $N$-nitrosoguanidine in rats. Cancer Res. 58, 4107-4112.

67) Takeuchi, M., Yamamoto, M., Tatematsu, M., Miki, K., Sakaki, Y. and Furihata, C. (2002) Dendritic cell appearance and differentiation during early and late stages of rat stomach carcinogenesis. Jpn. J. Cancer Res. 93, 925-934.

68) Maeng, H.Y., Choi, D.K., Takeuchi, M., Yamamoto, M., Tominaga, M., Tsukamoto, T. et al. (2002) Appearance of osteonectin-expressing fibroblastic cells in early rat stomach carcinogenesis and stomach tumors induced with $\mathrm{N}$ methyl- $N^{\prime}$-nitro- $N$-nitrosoguanidine. Jpn. J. Cancer Res. 93, 960-967.

69) Furihata, C. and Matsushima, T. (1987) Use of in vivo/in vitro unscheduled DNA synthesis for identification of organ-specific carcinogens. Crit. Rev. Toxicol. 17, 245-277.

70) Furihata, C. and Matsushima, T. (1995) In vivo short-term assays for tumor initiation and promotion in the glandular stomach of Fischer rats. Mutat. Res. 339, 15-35.

71) Furihata, C., Yoshida, S., Sato, Y. and Matsushima, T. (1987) Inductions of ornithine decarboxylase and DNA synthesis in rat stomach mucosa by glandular stomach carcinogens. Jpn. J. Cancer Res. 78, 1363-1369.

72) Furihata, C., Yoshida, S. and Matsushima, T. (1985) Potential initiating and promoting activities of diacetyl and glyoxal in rat stomach mucosa. Jpn. J. Cancer Res. 76, 809-814.

73) Furihata, C., Hatta, A., Sato, Y. and Matsushima, T. (1989) Alkaline elution of DNA from stomach pyloric mucosa of rats treated with glyoxal. Mutat. Res. 213, 227-231.

74) Furihata, C., Yamakoshi, A., Matsushima, T., Kato, T. and Kikugawa, K. (1988) Possible tumour-initiating and -promoting activities of 3diazo- $N$-nitrosobamethan in rat stomach mucosa. Mutagenesis 3, 299-301.

75) Ohshima, H., Furihata, C., Matsushima, T. and Bartsch, H. (1989) Evidence of potential tumourinitiating and tumour-promoting activities of hickory smoke condensate when given alone or with nitrite to rats. Food Chem. Toxicol. 27, 511516.

76) Shichino, Y., Tatematsu, M., Ohshima, H., Bartsch, H., Furihata, C. and Ito, N. (1992) Effects of hickory-smoke condensate on development of pepsinogen 1-altered pyloric glands in rats. Food Chem. Toxicol. 30, 859-864.

77) Furihata, C., Hirose, K. and Matsushima, T. (1991) Genotoxicity and cell proliferative activity of omeprazole in rat stomach mucosa. Mutat. Res. 262, 73-76.

78) Kakei, N., Ichinose, M., Tsukada, S., Tatematsu, M., Tezuka, N., Furihata, C. et al. (1993) Effects of omeprazole on gastric mucosal growth and differentiation in developing rat. Biochem. Biophys. Res. Commun. 97, 310-318.

79) Kakei, N., Ichinose, M., Tatematsu, M., Shimizu, M., Oka, M., Yahagi, N. et al. (1995) Effects of long-term omeprazole treatment on adult rat gastric mucosa-enhancement of the epithelial cell proliferation and suppression of its differentiation. Biochem. Biophys. Res. Commun. 214, 861-868.

80) Tepsuwan, A., Furihata, C., Rojanapo, W. and Matsushima, T. (1992) Genotoxicity and cell proliferative activity of a nitrosated Oroxylum indicum Vent fraction in the pyloric mucosa of rat stomach. Mutat. Res. 281, 55-61.

81) Furihata, C., Oka, M., Amin, S., Krzeminski, J., Weisburger, J.H., Kobayashi, K. et al. (1996) Effect of 2-chloro-4-methylthiobutanoic acid in a rapid bioassay for gastric carcinogens. Cancer Lett. 108, 129-135.

82) Furihata, C., Oguchi, S. and Matsushima, T. (1993) Possible tumor-initiating and -promoting activity of $p$-methylcatechol and methylhydroquinone in the pyloric mucosa of rat stomach. Jpn. J. Cancer Res. 84, 223-229.

83) Furihata, C., Ikui, E. and Matsushima, T. (1995) DNA damaging and cell proliferative activity of 1-methyl-1-nitrosourea in rat glandular stomach mucosa. Mutat. Res. 348, 169-173.

84) Tatematsu, M., Takahashi, M., Fukushima, S., Hananouchi, M. and Shirai, T. (1975) Effects in rats of sodium chloride on experimental gastric cancers induced by $N$-methyl- $N^{\prime}$-nitro- $N$-nitrosoguanidine or 4-nitroquinoline 1-oxide. J. Natl. Cancer Inst. 55, 101-106.

85) Takahashi, M., Nishikawa, A., Furukawa, F., Enami, T., Hasegawa, T. and Hayashi, Y. (1994) Dose-dependent promoting effects of sodium 
chloride $(\mathrm{NaCl})$ on rat glandular stomach carcinogenesis initiated with $N$-methyl- $N^{\prime}$-nitro- $N$-nitrosoguanidine. Carcinogenesis 15, 1429-1432.

86) Furihata, C., Sato, Y., Hosaka, M., Matsushima, T., Furukawa, F. and Takahashi, M. (1984) $\mathrm{NaCl}$ induced ornithine decarboxylase and DNA synthesis in rat stomach mucosa. Biochem. Biophys. Res. Commun. 121, 1027-1032.

87) Furihata, C., Ohta, H. and Katsuyama, T. (1996) Cause and effect between concentration-dependent tissue damage and temporary cell proliferation in rat stomach mucosa by $\mathrm{NaCl}$, a stomach tumor promoter. Carcinogenesis 17, 401-406.

88) Furihata, C., Sudo, K. and Matsushima, T. (1989) Calcium chloride inhibits stimulation of replicative DNA synthesis by sodium chloride in the pyloric mucosa of rat stomach. Carcinogenesis 10, 2135-2137.

89) Furihata, C. and Matsushima, T. (1990) Possible antitumor promoter in the glandular stomach: calcium chloride. Basic Life Sci. 52, 395-400.

90) Furihata, C., Ishida, S., Ohta, H., Tokuyama, T., Katsuyama, T. and Ogita, Z. (1996) Cytotoxicity of $\mathrm{NaCl}$, a stomach tumor promoter, and prevention by rice extract in stomach mucosa of F344 rats. Cancer Detect. Prev. 20, 193-198.

91) Furihata, C., Sato, Y., Matsushima, T. and Tatematsu, M. (1985) Induction of ornithine decarboxylase and DNA synthesis in rat stomach mucosa by methylglyoxal. Carcinogenesis $\mathbf{6}, 91-$ 94.

92) Furihata, C., Takezawa, R., Matsushima, T. and Tatematsu, M. (1987) Potential tumor-promoting activity of bile acids in rat glandular stomach. Jpn. J. Cancer Res. 78, 32-39.

93) Furihata, C., Sato, Y., Yamakoshi, A., Takimoto, M. and Matsushima, T. (1987) Inductions of ornithine decarboxylase and DNA synthesis in rat stomach mucosa by 1-nitrosoindole-3-acetonitrile. Jpn. J. Cancer Res. 78, 432-435.

94) Furihata, C., Yoshida, S., Sato, Y. and Matsushima, T. (1987) Inductions of ornithine decarboxylase and DNA synthesis in rat stomach mucosa by glandular stomach carcinogens. Jpn. J. Cancer Res. 78, 1363-1369.

95) Furihata, C., Yamakoshi, A. and Matsushima, T. (1988) Inductions of ornithine decarboxylase and DNA synthesis in rat stomach mucosa by formaldehyde. Jpn. J. Cancer Res. 79, 917-920.

96) Furihata, C., Hatta, A. and Matsushima, T. (1989) Inductions of ornithine decarboxylase and replicative DNA synthesis but not DNA single strand scission or unscheduled DNA synthesis in the pyloric mucosa of rat stomach by catechol. Jpn. J. Cancer Res. 80, 1052-1057.

97) Furihata, C., Yamakoshi, A., Takezawa, R. and Matsushima, T. (1989) Various sodium salts, potassium salts, a calcium salt and an ammonium salt induced ornithine decarboxylase and stimulated DNA synthesis in rat stomach mucosa. Jpn. J. Cancer Res. 80, 424-429.

98) Kim, D.J., Park, C.B., Lee, J.S., Tsuda, H. and
Furihata, C. (1999) Enhanced quinone reductase (QR) activity correlates with promotion potential of diethyl maleate (DEM) in rat forestomach and glandular stomach carcinogenesis initiated with $N$-methyl- $N$-nitro- $N$-nitrosoguanidine (MNNG). Cancer Lett. 137, 193-200.

99) Praud, D., Rota, M., Pelucchi, C., Bertuccio, P., Rosso, T., Galeone, C. et al. (2018) Cigarette smoking and gastric cancer in the Stomach Cancer Pooling (StoP) Project. Eur. J. Cancer Prev. 27, 124-133.

100) Deng, W., Jin, L., Zhuo, H., Vasiliou, V. and Zhang, Y. (2021) Alcohol consumption and risk of stomach cancer: A meta-analysis. Chem. Biol. Interact. 336, 109365.

101) Esumi, H., Sato, S., Sugimura, T. and Furihata, C. (1978) Purification of mouse pepsinogens by pepstatin-affinity chromatography. FEBS Lett. 86, 33-36.

102) Kataoka, K., Takeoka, Y. and Furihata, C. (1990) Immunocytochemical study of pepsinogen 1-producing cells in the fundic mucosa of the stomach in developing mice. Cell Tissue Res. 261, 211-217.

103) Yamamoto, M., Furihata, C., Fujimitsu, Y., Imai, T., Inada, K., Nakanishi, H. et al. (1997) Dosedependent induction of both pepsinogen-altered pyloric glands and adenocarcinomas in the glandular stomach of $\mathrm{C} 3 \mathrm{H}$ mice treated with $\mathrm{N}$ methyl- $N$-nitrosourea. Jpn. J. Cancer Res. 88, 238-244.

104) Kobayashi, K., Inada, K., Furihata, C., Tsukamoto, T., Ikehara, Y., Yamamoto, M. et al. (1999) Effects of low dose catechol on glandular stomach carcinogenesis in BALB/c mice initiated with $\mathrm{N}$ methyl- $N$-nitrosourea. Cancer Lett. 139, 167-172.

105) Yamamoto, M., Tsukamoto, T., Sakai, H., Shirai, N., Ohgaki, H., Furihata, C. et al. (2000) p53 knockout mice $(-/-)$ are more susceptible than $(+/-)$ or $(+/+)$ mice to $N$-methyl- $N$-nitrosourea stomach carcinogenesis. Carcinogenesis 21, 18911897.

106) Yamamoto, M., Furihata, C., Ogiu, T., Tsukamoto, T., Inada, K., Hirano, K. et al. (2002) Independent variation in susceptibilities of six different mouse strains to induction of pepsinogen-altered pyloric glands and gastric tumor intestinalization by $N$-methyl- $N$-nitrosourea. Cancer Lett. 179, 121-132.

107) Yoshizawa, N., Yamaguchi, H., Yamamoto, M., Shimizu, N., Furihata, C., Tatematsu, M. et al. (2009) Gastric carcinogenesis by $N$-methyl- $N$ nitrosourea is enhanced in $\mathrm{db} / \mathrm{db}$ diabetic mice. Cancer Sci. 100, 1180-1185.

108) Furihata, C., Tatematsu, M., Saito, M., Ishida, S., Nakanishi, H., Inada, K. et al. (1997) Rare occurrence of ras and $p 53$ gene mutations in mouse stomach tumors induced by $N$-methyl- $N$ nitrosourea. Jpn. J. Cancer Res. 88, 363-368.

109) Saxl, P. (1915) Úber das Vorkommen und der Nachweis von Pepsin im Blutserum. Wien. Klin. Wochenschr. 65, 458-459.

110) Anscombe, A.R. (1964) Plasma pepsinogen: Normal 
and abnormal secretion (1964). Ann. R. Coll. Surg. Engl. 35, 34-49.

111) Samloff, I.M. (1969) Slow moving protease and the seven pepsinogens. Electrophoretic demonstration of the existence of eight proteolytic fractions in human gastric mucosa. Gastroenterology 57, 659669.

112) Samloff, I.M. and Townes, P.L. (1970) Electrophoretic heterogeneity and relationships of pepsinogens in human urine, serum, and gastric mucosa. Gastroenterology 58, 462-469.

113) Samloff, I.M. (1971) Pepsinogens, pepsins, and pepsin inhibitors. Gastroenterology 60, 586-604.

114) Samloff, I.M. and Liebman, W.M. (1973) Cellular localization of the group II pepsinogens in human stomach and duodenum by immunofluorescence. Gastroenterology 65, 36-42.

115) Hirsch-Marie, H., Loisillier, F., Touboul, J.P. and Burtin, P. (1976) Immunochemical study and cellular localization of human pepsinogens during ontogenesis and in gastric cancers. Lab. Invest. 34, 623-632.

116) Nomura, A.M., Stemmermann, G.N. and Samloff, I.M. (1980) Serum pepsinogen I as a predictor of stomach cancer. Ann. Intern. Med. 93, 537-540.

117) Miki, K., Ichinose, M., Shimizu, A., Huang, S.C., Oka, H., Furihata, C. et al. (1987) Serum pepsinogens as a screening test of extensive chronic gastritis. Gastroenterol. Jpn. 22, 133-141.

118) Furihata, C., Tatematsu, M., Miki, K., Katsuyama, T., Sudo, K., Miyagi, N. et al. (1984) Gastric- and intestinal-type properties of human gastric cancers transplanted into nude mice. Cancer Res. 44, $727-733$.

119) Tatematsu, M., Furihata, C., Katsuyama, T., Miki, K., Honda, H., Konishi, Y. et al. (1986) Gastric and intestinal phenotypic expressions of human signet ring cell carcinomas revealed by their biochemistry, mucin histochemistry, and ultrastructure. Cancer Res. 46, 4866-4872.

120) Ichinose, M., Miki, K., Furihata, C., Kageyama, T., Niwa, H., Oka, H. et al. (1982) Radioimmunoassay of group II pepsinogen in human serum. Clin. Chim. Acta 122, 61-69.

121) Ichinose, M., Miki, K., Furihata, C., Kageyama, T., Hayashi, R., Niwa, H. et al. (1982) Radioimmunoassay of serum group I and group II pepsinogens in normal controls and patients with various disorders. Clin. Chim. Acta 126, 183-191.

122) Miki, K., Ichinose, M., Furihata, C., Niwa, H., Oka, H., Oda, T. et al. (1982) Potential peptic activity of pepsinogen of human gastroduodenal mucosa determined by fluorescent microassay method using succinyl albumin. Clin. Chim. Acta 121, 337-344.

123) Huang, S.C., Miki, K., Hirano, K., Hayashi, Y., Furihata, C., Shimizu, A. et al. (1987) Enzymelinked immunosorbent assay of serum pepsinogen I. Clin. Chim. Acta 162, 85-96.

124) Huang, S.C., Miki, K., Furihata, C., Ichinose, M., Shimizu, A. and Oka, H. (1988) Enzyme-linked immunosorbent assays for serum pepsinogens I and II using monoclonal antibodies — with data on peptic ulcer and gastric cancer. Clin. Chim. Acta 175, 37-50.

125) Huang, S.C., Miki, K., Sano, J., Ichinose, M., Kawamura, N., Oka, H. et al. (1988) Pepsinogens I and II in gastric cancer: an immunohistochemical study using monoclonal antibodies. Jpn. J. Cancer Res. 79, 1139-1146.

126) Miki, K., Ichinose, M., Kawamura, N., Matsushima, M., Ahmad, H.B., Kimura, M. et al. (1989) The significance of low serum pepsinogen levels to detect stomach cancer associated with extensive chronic gastritis in Japanese subjects. Jpn. J. Cancer Res. 80, 111-114.

127) Miki, K., Morita, M., Sasajima, M., Hoshina, R., Kanda, E. and Urita, Y. (2003) Usefulness of gastric cancer screening using the serum pepsinogen test method. Am. J. Gastroenterol. 98, 735739 .

128) Miki, K. and Urita, Y. (2007) Using serum pepsinogens wisely in a clinical practice. J. Dig. Dis. 8, 8-14.

129) Miki, K., Ichinose, M., Ishikawa, K.B., Yahagi, N., Matsushima, M., Kakei, N. et al. (1993) Clinical application of serum pepsinogen I and II levels for mass screening to detect gastric cancer. Jpn. J. Cancer Res. 84, 1086-1090.

130) Kikuchi, S., Wada, O., Miki, K., Nakajima, T., Nishi, T., Kobayashi, O. et al. (1994) Serum pepsinogen as a new marker for gastric carcinoma among young adults. Research Group on Prevention of Gastric Carcinoma among Young Adults. Cancer 73, 2695-2702.

131) Ooi, H., Furihata, S. and Miki, K. (2000) Resident medical examination of gastric cancer by the pepsinogen method in Adachi-ku, Tokyo. J. Gastroenterol. Cancer Screening 38, 677-682 (in Japanese).

132) Miki, K., Fujishiro, M., Kodashima, S. and Yahagi, N. (2009) Long-term results of gastric cancer screening using the serum pepsinogen test method among an asymptomatic middle-aged Japanese population. Dig. Endosc. 21, 78-81.

133) Ichinose, M., Miki, K., Tatematsu, M., Furihata, C., Nobuhara, M., Ichihara, Y. et al. (1988) Hypomethylation and expression of pepsinogen A genes in the fundic mucosa of human stomach. Biochem. Biophys. Res. Commun. 151, 275-282.

134) Ichinose, M., Miki, K., Wong, R.N., Tatematsu, M., Furihata, C., Konishi, T. et al. (1991) Methylation and expression of human pepsinogen genes in normal tissues and their alteration in stomach cancer. Jpn. J. Cancer Res. 82, 686-692.

135) Maekita, T., Nakazawa, K., Mihara, M., Nakajima, T., Yanaoka, K., Iguchi, M. et al. (2006) High levels of aberrant DNA methylation in Helicobacter pylori-infected gastric mucosae and its possible association with gastric cancer risk. Clin. Cancer Res. 12, 989-995.

136) Yoshida, T., Kato, J., Maekita, T., Yamashita, S., Enomoto, S., Ando, T. et al. (2013) Altered mucosal DNA methylation in parallel with highly 
active Helicobacter pylori-related gastritis. Gastric Cancer 16, 488-497.

137) Ando, T., Yoshida, T., Enomoto, S., Asada, K., Tatematsu, M., Ichinose, M. et al. (2009) DNA methylation of microRNA genes in gastric mucosae of gastric cancer patients: its possible involvement in the formation of epigenetic field defect. Int. J. Cancer 124, 2367-2374.

138) Niwa, T., Tsukamoto, T., Toyoda, T., Mori, A., Tanaka, H., Maekita, T. et al. (2010) Inflammatory processes triggered by Helicobacter pylori infection cause aberrant DNA methylation in gastric epithelial cells. Cancer Res. 70, 1430-1440.

139) Kim, J.G., Takeshima, H., Niwa, T., Rehnberg, E., Shigematsu, Y., Yoda, Y. et al. (2013) Comprehensive DNA methylation and extensive mutation analyses reveal an association between the $\mathrm{CpG}$ island methylator phenotype and oncogenic mutations in gastric cancers. Cancer Lett. 330, 3340.

140) Asada, K., Nakajima, T., Shimazu, T., Yamamichi, N., Maekita, T., Yokoi, C. et al. (2015) Demonstration of the usefulness of epigenetic cancer risk prediction by a multicentre prospective cohort study. Gut 64, 388-396.

141) Correa, P. (1992) Human gastric carcinogenesis: A multistep and multifactorial process - First American Cancer Society Award lecture on cancer epidemiology and prevention. Cancer Res. 52, 6735-6740.

142) Lee, T.Y., Wang, R.C., Lee, Y.C., Lin, J.T., Ho, H.J., Hsieh, M.C. et al. (2016) The incidence of gastric adenocarcinoma among patients with gastric intestinal metaplasia: A long-term cohort study. J. Clin. Gastroenterol. 50, 532-537.

143) Spence, A.D., Cardwell, C.R., McMenamin, Ú.C., Hicks, B.M., Johnston, B.T., Murray, L.J. et al. (2017) Adenocarcinoma risk in gastric atrophy and intestinal metaplasia: a systematic review. BMC Gastroenterol. 17, 157.

144) Tatematsu, M., Ichinose, M., Miki, K., Hasegawa, R., Kato, T. and Ito, N. (1990) Gastric and intestinal phenotypic expression of human stomach cancers as revealed by pepsinogen immunohistochemistry and mucin histochemistry. Acta Pathol. Jpn. 40, 494-504.

145) Yoshikawa, A., Inada, K., Yamachika, T., Shimizu, N., Kaminishi, M. and Tatematsu, M. (1998) Phenotypic shift in human differentiated gastric cancers from gastric to intestinal epithelial cell type during disease progression. Gastric Cancer 1, $134-141$.

146) Kinoshita, H., Hayakawa, Y. and Koike, K. (2017) Metaplasia in the Stomach-Precursor of Gastric Cancer? Int. J. Mol. Sci. 18, 2063.

147) Graham, D.Y. and Zou, W.Y. (2018) Guilt by association: intestinal metaplasia does not progress to gastric cancer. Curr. Opin. Gastroenterol. 34, 458-464.

148) PGA3 (pepsinogen A3) [Homo sapiens (human)]. Gene ID: 643834. NCBI, Bethesda, MD, U.S.A. https://www.ncbi.nlm.nih.gov/gene/643834.
149) PGA4 (pepsinogen A4) [Homo sapiens (human)]. Gene ID: 643847. NCBI, Bethesda, MD, U.S.A. https://www.ncbi.nlm.nih.gov/gene/643847.

150) PGA5 (pepsinogen A5) [Homo sapiens (human)]. Gene ID: 5222. NCBI, Bethesda, MD, U.S.A. https://www.ncbi.nlm.nih.gov/gene/5222.

151) Sogawa, K., Fujii-Kuriyama, Y., Mizukami, Y., Ichihara, Y. and Takahashi, K. (1983) Primary structure of human pepsinogen gene. J. Biol. Chem. 258, 5306-5311.

152) Taggart, R.T., Mohandas, T.K., Shows, T.B. and Bell, G.I. (1985) Variable numbers of pepsinogen genes are located in the centromeric region of human chromosome 11 and determine the highfrequency electrophoretic polymorphism. Proc. Natl. Acad. Sci. U.S.A. 82, 6240-6244.

153) Pepsinogen 3, group I (pepsinogen A) [Homo sapiens]. GenBank: AAI71815.1. NCBI, Bethesda, MD, U.S.A. https://www.ncbi.nlm.nih.gov/ protein/AAI71815.

154) Pepsinogen 4, group I (pepsinogen A) [Homo sapiens]. GenBank: AAI71910.1. NCBI, Bethesda, MD, U.S.A. https://www.ncbi.nlm.nih.gov/ protein/AAI71910.

155) Pepsinogen 5, group I (pepsinogen A) [Homo sapiens]. GenBank: EAW73928.1. NCBI, Bethesda, MD, U.S.A. https://www.ncbi.nlm.nih.gov/ protein/EAW73928.

156) gastricsin isoform 1 preproprotein [Homo sapiens]. NCBI Reference Sequence: NP_002621.1. NCBI, Bethesda, MD, U.S.A. https://www.ncbi.nlm.nih. gov/protein/NP_002621.

157) gastricsin isoform 2 preproprotein [Homo sapiens]. NCBI Reference Sequence: NP_001159896.1. NCBI, Bethesda, MD, U.S.A. https://www.ncbi. nlm.nih.gov/protein/NP_001159896.

158) Konturek, J.W. (2003) Discovery by Jaworski of Helicobacter pylori and its pathogenetic role in peptic ulcer, gastritis and gastric cancer. J. Physiol. Pharmacol. 54 (Suppl. 3), 23-41.

159) Marshall, B.J. and Warren, J.R. (1984) Unidentified curved bacilli in the stomach of patients with gastritis and peptic ulceration. Lancet 1, 13111315.

160) IARC Working Group on the Evaluation of Carcinogenic Risks to Humans (1994) Infection with Helicobacter pylori. IARC Monogr. Eval. Carcinog. Risks Hum. 61, 177-240.

161) IARC Working Group on the Evaluation of Carcinogenic Risks to Humans (2012) Helicobacter pylori. IARC Monogr. Eval. Carcinog. Risks Hum. 100B, 385-436.

162) Hatakeyama, M. (2017) Structure and function of Helicobacter pylori CagA, the first-identified bacterial protein involved in human cancer. Proc. Jpn. Acad., Ser. B, Phys. Biol. Sci. 93, 196-219.

163) Asaka, M., Kato, M., Kudo, M., Katagiri, M., Nishikawa, K., Yoshida, J. et al. (1995) Relationship between Helicobacter pylori infection, atrophic gastritis and gastric carcinoma in a Japanese population. Eur. J. Gastroenterol. Hepatol. 7 (Suppl. 1), S7-S10. 
164) Asaka, M., Kimura, T., Kudo, M., Takeda, H., Mitani, S., Miyazaki, T. et al. (1992) Relationship of Helicobacter pylori to serum pepsinogens in an asymptomatic Japanese population. Gastroenterology 102, 760-766.

165) Inoue, M. (2017) Changing epidemiology of Helicobacter pylori in Japan. Gastric Cancer 20 (Suppl. 1), 3-7.

166) Kato, M., Ota, H., Okuda, M., Kikuchi, S., Satoh, K., Shimoyama, T. et al. (2019) Guidelines for the management of Helicobacter pylori infection in Japan: 2016 Revised Edition. Helicobacter 24, e12597.

167) Osumi, H., Fujisaki, J., Suganuma, T., Horiuchi, Y., Omae, M., Yoshio, T. et al. (2017) A significant increase in the pepsinogen I/II ratio is a reliable biomarker for successful Helicobacter pylori eradication. PLoS One 12, e0183980.

168) Asaka, M., Kimura, T., Kato, M., Kudo, M., Miki, K., Ogoshi, K. et al. (1994) Possible role of Helicobacter pylori infection in early gastric cancer development. Cancer 73, 2691-2694.

169) Kikuchi, S., Kurosawa, M., Sakiyama, T., Tenjin, H., Miki, K., Wada, O. et al. (2000) Long-term effect of Helicobacter pylori infection on serum pepsinogens. Jpn. J. Cancer Res. 91, 471-476.

170) Yanaoka, K., Oka, M., Yoshimura, N., Mukoubayashi, C., Enomoto, S., Iguchi, M. et al. (2008) Risk of gastric cancer in asymptomatic middle-aged Japanese subjects based on serum pepsinogen and Helicobacter pylori antibody levels. Int. J. Cancer 123, 917-926.

171) Miki, K. (2011) Gastric cancer screening by combined assay for serum anti-Helicobacter pylori IgG antibody and serum pepsinogen levels "ABC method". Proc. Jpn. Acad. Ser. B Phys. Biol. Sci. 87, 405-414.

172) Kudo, T., Kakizaki, S., Sohara, N., Onozato, Y., Okamura, S., Inui, Y. et al. (2011) Analysis of ABC (D) stratification for screening patients with gastric cancer. World J. Gastroenterol. 17, 47934798 .

173) Zhang, X., Xue, L., Xing, L., Wang, J., Cui, J., Mi, J. et al. (2012) Low serum pepsinogen I and pepsinogen I/II ratio and Helicobacter pylori infection are associated with increased risk of gastric cancer: 14-year follow up result in a rural Chinese community. Int. J. Cancer 130, 16141619.

174) Yoshida, T., Kato, J., Inoue, I., Yoshimura, N., Deguchi, H., Mukoubayashi, C. et al. (2014) Cancer development based on chronic active gastritis and resulting gastric atrophy as assessed by serum levels of pepsinogen and Helicobacter pylori antibody titer. Int. J. Cancer 134, 14451457.

175) Ikeda, F., Shikata, K., Hata, J., Fukuhara, M., Hirakawa, Y., Ohara, T. et al. (2016) Combina- tion of Helicobacter pylori antibody and serum; pesinogen as a good predictive tool of gastric cancer incidence: 20-year prospective data from the Hisayama study. J. Epidemiol. 26, 629-636.

176) Charvat, H., Sasazuki, S., Inoue, M., Iwasaki, M., Sawada, N., Shimazu, T. et al. (2016) Prediction of the 10-year probability of gastric cancer occurrence in the Japanese population: the JPHC study cohort II. Int. J. Cancer 138, 320-331.

177) Vohlonen, I., Pukkala, E., Malila, N., Härkönen, M., Hakama, M., Koistinen, V. et al. (2016) Risk of gastric cancer in Helicobacter pylori infection in a 15-year follow-up. Scand. J. Gastroenterol. 51, 1159-1164.

178) Sasazuki, S. (2016) The ABC method and gastric cancer: evidence from prospective studies. J. Epidemiol. 26, 611-612.

179) Park, C.H., Kim, E.H., Jung, D.H., Chung, H., Park, J.C., Shin, S.K. et al. (2016) The new modified ABCD method for gastric neoplasm screening. Gastric Cancer 19, 128-135.

180) Song, M., Camargo, M.C., Weinstein, S.J., Murphy, G., Freedman, N.D., Koshiol, J. et al. (2018) Serum pepsinogen 1 and anti-Helicobacter pylori IgG antibodies as predictors of gastric cancer risk in Finnish males. Aliment. Pharmacol. Ther. 47, 494-503.

181) Leja, M., Park, J.Y., Murillo, R., Liepniece-Karele, I., Isajevs, S., Kikuste, I. et al. (2017) Multicentric randomised study of Helicobacter pylori eradication and pepsinogen testing for prevention of gastric cancer mortality: the GISTAR study. BMJ Open 7, e016999.

182) Taniyama, Y., Katanoda, K., Charvat, H., Hori, M., Ohno, Y., Sasazuki, S. et al. (2017) Estimation of lifetime cumulative incidence and mortality risk of gastric cancer. Jpn. J. Clin. Oncol. 47, 1097-1102.

183) Saito, S., Azumi, M., Muneoka, Y., Nishino, K., Ishikawa, T., Sato, Y. et al. (2018) Cost-effectiveness of combined serum anti-Helicobacter pylori IgG antibody and serum pepsinogen concentrations for screening for gastric cancer risk in Japan. Eur. J. Health Econ. 19, 545-555.

184) Chiang, T.H., Chiu, S.Y., Chen, S.L., Yen, A.M., Fann, J.C., Liu, C.Y. et al. (2019) Serum pepsinogen as a predictor for gastric cancer death: A 16-year community-based cohort study. J. Clin. Gastroenterol. 53, e186-e193.

185) Inoue, M., Sawada, N., Goto, A., Shimazu, T., Yamaji, T., Iwasaki, M. et al. (2020) HighNegative anti-Helicobacter pylori IgG antibody titers and long-term risk of gastric cancer: results from a large-scale population-based cohort study in Japan. Cancer Epidemiol. Biomarkers Prev. 29, 420-426.

(Received July 1, 2021; accepted July 19, 2021) 


\section{Profile}

Chie Furihata was born in 1941 in Tokyo, Japan. She graduated from The University of Tokyo, Faculty of Science, Department of Biophysics and Biochemistry, and obtained her PhD from The University of Tokyo in 1970 under the supervision of Prof. Fujio Egami. She became a research associate in the Department of Molecular Oncology, Institute of Medical Science, The University of Tokyo (Prof. Takashi Sugimura and later Prof. Taijiro Matsushima) in 1971 and then lecturer in the same department. She started pioneering rat pepsinogen studies in rat gastric carcinogenesis induced by MNNG under the supervision of Prof. Sugimura and collaborated with Drs. Masae Tatematsu and Michihito Takahashi. She collaborated on human pepsinogen studies in human gastric cancer with Drs. Kazumasa Miki, Masao Ichinose, Kenji

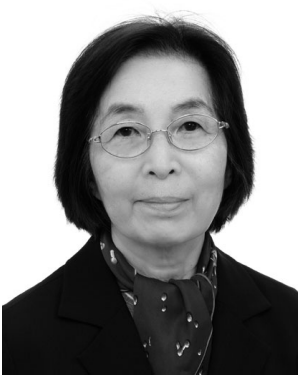
Takahashi, and Takashi Kageyama. She became Professor of the School of Science and Engineering at Aoyama Gakuin University in 1999 and is currently Emeritus Professor of Aoyama Gakuin University and Visiting Scholar of National Institute of Health Sciences and a member of Japan Research Foundation of Prediction, Diagnosis and Therapy for Gastric Cancer. Recently, she conducted chemical risk assessment studies mainly on carcinogens. She received an award from the Japanese Environmental Mutagen Society and is an honorary member of the society. 